\title{
Determinants of Dividend Smoothing: Empirical evidence from non-financial firms listed on Vietnam stock exchanges
}

\author{
Thanh Tat Tran \\ School of Banking and Finance \\ National Economics University, \\ Vietnam \\ Giai Phong Street, Hai Ba Trung \\ District, Ha Noi, Viet Nam \\ trantatthanh@neu.edu.vn
}

\author{
Dinh Van Nguyen \\ International School \\ Vietnam National University - Hanoi, \\ Vietnam \\ Xuan Thuy Street, Cau Giay District, \\ Ha Noi, Viet Nam \\ dinhnv@isvnu.vn
}

\author{
Yen Hai Thi Nguyen \\ Faculty of Business Management \\ Hanoi University of Industry, \\ Viet Nam \\ Cau Dien Street, North Tu Liem \\ District, Ha Noi, Viet Nam \\ yennth@haui.edu.vn
}

\begin{abstract}
This study considers the impact of different factors on the degree of dividend smoothing of non-financial firms listed in Vietnam during 2008 - 2018. We use two measures (Speed of Adjustment and Relative Volatility) to evaluate the degree of dividend smoothing. Using 2SLS estimation to solve endogenous issues in the model, we show that dividend smoothing is higher for firms with fragmented ownership structure, slim growth opportunities, large size, high-profit volatility and are in the highly competitive sector. We also contribute to the literature by the new finding that the firm age has a nonlinear relation ( $U$-shaped) with the degree of dividend smoothing. Our results support the agency theory.
\end{abstract}

Index Terms-dividend smoothing, speed of adjustment, relative volatility

\section{INTRODUCTION}

$\mathrm{D}$ IVIDEND smoothing has drawn attention from many researchers after the seminal paper by Lintner [24]. Accordingly, dividend smoothing implies an attempt by corporate managers to adjust dividend payments in response to changes in earnings in order to maintain a stable dividend policy.

Existing studies on factors affecting dividend smoothing have been done in developed and emerging markets. In Vietnam, to the best of our knowledge, research on this relationship is somewhat limited. With the characteristics of a market with low liquidity and limited access to the market (such as: openness of the market and equal rights with foreign investors, limited public sector, information disclosure, ect), Vietnamese stock market is currently a frontier market and is waiting to be upgraded to an emerging market. Because of the differences in macroeconomic environment, corporate governance, agency issues and potential information asymmetry for firms, investigating factors affecting dividend smoothing in Vietnam is necessary to provide a new perspective in the new context.

Previous studies have investigated the impact of ownership structure on the dividend smoothing behavior of firms, but these studies mainly mention the role of ownership concentration and institutional ownership. Meanwhile, ownership structure in Vietnam is characterized by centralized ownership and state ownership. The state-owned firms in Vietnam are characterized by the dominant shares of the State. With this feature, in addition to the variables of centralized ownership and institutional ownership, it is neces- sary to evaluate the influence of State ownership on the behaviour of dividend smoothing in Vietnam.

In addition, there are two main measures of dividend smoothing: the SOA-speed of adjustment proposed by Litner [24] and relative volatility (RelVol) by Leary and Michaely [23]. RelVol is a measure that has many advantages that SOA does not have such as: Avoiding bias when the sample is small (short sample size and a limited number of observations). However, most previous studies used the traditional SOA to measure the degree of dividend smoothing. Therefore, using RelVol to consider the impact of different factors on dividend smoothing in Vietnam is also a research gap. We fill this gap by investigating the impact of different factors on dividend smoothing using both RelVol and SOA to measure dividend smoothing.

\section{Theoretical Background and Literature Review}

We employ two fundamental theories: the signalling theory and the agency theory. Signalling theory says that dividend smoothing is to minimize problems arising from information asymmetry [6]. This is a means of signalling about earnings prospects. Firms that have to face more information asymmetry will be likely to smooth their dividends [20], [19], [13].

The agency theory states that dividend smoothing is seen as a means of controlling the agency costs to harmonize benefits among stakeholders [10], [8], [3], [22]. The more the firm has potential conflicts of interest, the higher the level of dividend smoothing.

Thus, according to the above arguments, asymmetric information and agency problems affect the firm's dividend policy. Firms that face larger conflicts of interest and asymmetric information tend to smooth their dividends more. Therefore, the stability of dividends of the listed firms depends on intrinsic characteristics such as: firm age, level of risk, ownership structure, growth opportunities.

Research on factors affecting dividend smoothing of firms is still limited. Some studies are: Leary and Michaely [23], Javakhadze et al [15] and Jeong [17]. These studies aimed at testing the factors affecting the level of dividend smoothing based on information asymmetry and agency problems. The research results have contributed to providing evidence on dividend smoothing in the Korean and American markets. However, using only SOA to measure dividend 
smoothing in the study of Jeong and Javakhadze et al may not be enough to confirm the robustness of the results. Regarding research methods, if these studies control the endogenous issues in the model, the research results will be more reliable.

Besides the studies on the above factors affecting dividend smoothing, a number of studies focus on testing the relationship between ownership structure, board structure and dividend smoothing [25], [2], or the relationship between dividend change and cash flow [18].

\section{Hypotheses and Research Models}

\section{A. Research hypothesis}

We focus on the following research question: How do characteristics of firms and business sectors affect the degree of dividend smoothing of non-financial firms listed on the Vietnam stock market? To answer the question, we used a group of factors including characteristics of firms and the business sector proposed from the theories of information asymmetry and agency problem.

* Firm size and firm age: Size and age represent the maturity of the firm. Large and long-standing firms are more trustworthy because historical data is available. Investors have easier access to information than newly listed and small firms. These firms are expected to have a lower potential for information asymmetry than younger and smaller firms [22]. Meanwhile, the problem of information asymmetry is considered to be more serious for small and/or newly listed firms because of the lack of historical data or reputation.

Dividend signaling theory argues that in the presence of asymmetric information, a firm's dividends can convey reliable information from insiders (managers). Freeman [11] reported that the market prices of large firms more accurately reflect earnings than those of small firms. Thus, it can be seen that smaller firms tend to use dividends as a signal of value. All these arguments imply that the size and age of the firm may reduce the signaling function, thus reducing the degree of dividend smoothing. Therefore, we expect the following hypotheses:

H1: Firm size has a negative impact on the degree of dividend smoothing.

H2: Firm age has a negative impact on the degree of dividend smoothing.

*Growth opportunity: According to signalling theory, firms with higher expected growth opportunities have higher demand for funding. To meet the capital needs, these firms have to use the dividend signal by maintaining dividend payment stable relative to income. Therefore, investment opportunities will be an incentive for firms to smooth dividends [1], [17]. On the other hand, when investment opportunities increase, it will reduce the free cash flow of firms due to the need to retain income to meet capital needs, which will reduce agency conflicts between shareholders and managers. Firms are less likely to implement a stable dividend policy in this case.

With the characteristics of the Vietnam stock market, asymmetric information is always a big problem in the busi- ness environment of firms, therefore, firm managers often tend to transmit signals about earnings prospects to investors. Therefore, we expect a positive relationship between growth opportunities and dividend smoothing as follows:

H3: Growth opportunities have a positive impact on the degree of dividend smoothing.

* Cash flow: The separation between ownership and control is one of the fundamental tenets of the market that creates the agency problem. Jensen and Meckling [16] argue that free cash flow will create temptation for managers to choose investment projects, managers can have an incentive to invest this excess cash flow in projects with low efficiency to increase the size of the firm or increase the level of management control. This fact may lead to a decrease in the value of the firm. The conflict of interest increases as the free cash flow of the firm increases. Therefore, dividend smoothing not only conveys information about a firm's earnings prospect but also management's commitment not to overinvest to harm shareholders' interests. The following hypothesis reflects the above analyses:

H4: Firms with high free cash flows tend to exercise dividend smoothing more.

* Firm risk: Asymmetric information makes high-risk firms more inclined to stabilize their dividend [20], [13]. Firms with more stable profits can predict future returns more accurately, and thus managers can pay dividends without worrying about future dividend cuts. This view is also consistent with the studies of Aivazian et al [1] and Jeong [17]. The following hypothesis is proposed:

H5: Firms with high risk have a positive impact on the degree of dividend smoothing.

* Ownership structure: The concentration of ownership reduces conflicts of interest, which in turn reduces agency costs. In contrast, in firms with dispersed ownership, there are potential conflicts of interest between controlling shareholders and major shareholders. Dividend smoothing can be used to mitigate this conflict of interest by reducing free cash flow and forcing firms to raise external funds from the capital market and strengthen supervision from the capital market [10]. Several results from empirical studies support this view [21], [25]. Therefore, the next hypothesis is as follows:

H6.1: The ownership ratio of larger shareholders is negatively associated with the degree of dividend smoothing.

Institutional shareholder ownership is represented for all three market conflicts (taxes, asymmetric information, and agency conflicts). From a tax point of view, institutional shareholders are not at a disadvantage in terms of dividend tax like individual shareholders. According to the agency theory, institutional shareholders are those who have strong supervisory ability and have advantages in the management of firms. The presence of institutional shareholders reduces conflicts of interest and agency problems. On the other hand, if the argument is based on the problem of information asymmetry, institutional shareholders are knowledgeable people who have easier access to information than individual shareholders, so the problem of asymmetric information 
is minimized if there is a large ownership percentage of institutional shareholders in a firm [7] .

Starting from the problem of information asymmetry, the study expects signalling theory to be the basis for explaining this relationship in Vietnam's stock market. The following hypothesis is proposed:

H6.2: The percentage of stock holdings of institutional shareholders has a negative impact on the degree of dividend smoothing.

The current state of ownership structure in Vietnam is a centralized ownership structure and the State holds the dominant power in a number of firms in a number of important economic sectors such as Oil and Gas and Utilities. Although the privatization is still being implemented, the number of firms owned by the State is not small. Firms with state control will face fewer agency problems, so they are less likely to smooth dividends. Thus, in addition to the ownership of major shareholders and institutional ownership, we add the following hypothesis:

H6.3: State ownership rate has a negative impact on the degree of dividend smoothing.

* Sectoral competition: The higher the level of competition in the sector, the lower the agency problem because firms must focus on improving competitiveness. Faced with great competition for capital, it is likely that managers will respond to investors' preferences for dividends [5] to attract funds. This means that firms tend to use dividends as a means to transmit signals to attract funds. According to this argument, firms operating in highly competitive sectors are more likely to smooth dividends. The following hypothesis is proposed:

H7: The level of sector competition has a positive impact on the degree of dividend smoothing.

* Asset tangibility: According to Harris and Raviv [14], it is easier for an outsider to control tangible assets than intangible assets because of the physical form of tangible assets. Therefore, a large proportion of investments in tangible assets will reduce the uncertainty of the firm's information. Therefore, we expect the following hypotheses:

H8: The proportion of tangible assets has a negative impact on the degree of dividend smoothing.

* The volatility of returns of the sector: The phenomenon of dividend smoothing will be more common in sectors where the volatility of returns seems to be higher. The return volatility of a sector is commonly used to assess the uncertainty of a sector's information [15]. We propose the following hypothesis:

H9: Firms in sectors with large profit fluctuations tend to smooth dividends more.

\section{B. Research models}

To test the above hypotheses, we implement the following multivariable regression model:

$$
\begin{aligned}
\operatorname{RelVol}_{i}\left(\mathrm{SOA}_{i}\right)= & \beta_{0}+\beta_{1} O \mathrm{OWN}_{i}+\beta_{2} A G E_{i}+\beta_{3} \mathrm{SI} \mathrm{ZE}_{i} \\
+\beta_{4} \mathrm{GROWTH}_{i}+\beta_{5} & \mathrm{FCF}_{i}+\beta_{6} \text { RISK }_{i}+\beta_{7} \mathrm{HHI}_{i}+\beta_{8} \text { TANG }_{i} \\
& +\beta_{9} \text { RISK }_{I N D i}+\varepsilon_{i}
\end{aligned}
$$

The dependent variable is the degree of dividend smoothing using simultaneously two measures SOA and RelVol. SOA is estimated from the model of Lintner and RelVol
(Relative Volatility) is proposed by Leary and Michaely. In which:

\section{$>\quad$ Lintner model (1956):}

$$
D P S_{i, t}-D P S_{i, t-1}=\alpha+\beta_{1} D P S_{i, t-1}+\beta_{2} E P S_{i, t}+u_{i, t}
$$

Where: $D P S_{t}$ is the dividend of the year t; $E P S_{t}$ is the current income. The level of dividend smoothing SOA is the value $-\beta 1$ regressed from equation (1).

Leary and Michaely model (2011)

$$
\begin{gathered}
\text { Adj.DPS } \text { D }_{i t}=\alpha_{1}+\beta_{1} * t+\beta_{2} * t^{2}+\varepsilon_{i t} \\
T_{P R_{i} * \text { Adj } . E P S_{i t}=\alpha_{2}+\gamma_{1} * t+\gamma_{2} * t^{2}+\mu_{i t}} \\
\text { RelVol }=\frac{\sigma(\varepsilon)}{\sigma(\mu)}
\end{gathered}
$$

Where: Adj.DPS it is the dividend paid by firm i at time $t$ after correction to eliminate volatility due to the stock split; $T P R_{i}$ is the assumed target payout ratio, assumed by Leary and Michaely [23] to be equal to the median of the firm's payment rate over the study period; Adj.EPS it is the earnings per share of a firm at time $t$ after corrected to eliminate fluctuations due to a stock split; $t$ is the time trend variable numbered from 1 to $n$ corresponding to the number of periods observed in the sample. The RelVol measure is the ratio of the root-mean-square error (RMSE) from the first equation to RMSE from the second equation.

The independent variables in the model are described in the table I below.

\section{Data and Sample Selection}

\section{A. Research sample}

The study sample was selected for the following criteria:

- Firstly, listed firms are more likely to use signals from dividends to transmit information about their performance to their investors because they must satisfy the stock listing conditions and the regulations on information disclosure. Therefore, the listed firms are more suitable for dividend smoothing behavior than the unlisted firms [25].

- Second, smoothing dividends is a process, so the research unit is the firms that pay dividends, which have enough data to calculate the smoothing measures [9]. We excluded the firms in the financial sector because this sector is governed by its own regulations and has a specific financial report structure. Also, this sample does not include firms that adjust data in the research period such as implementing equitization or participating in M\&A business [23].

- Third, to determine the factors affecting the level of dividend smoothing, it is necessary to identify proxies that represent market conflicts. These variables require that data must have not more than 5 years of missing values [23].

\section{B. Research period}

We collect data of firms in the period from 2008 to 2018. Particularly data on dividend (DPS) was collected 12 years 
TABLE I

Describe The Independent Variables And Sign Expectation With THEORETICAL

\begin{tabular}{|c|c|c|c|}
\hline $\begin{array}{l}\text { Variable } \\
\text { name }\end{array}$ & $\begin{array}{l}\text { Variable } \\
\text { code }\end{array}$ & Identification method & $\begin{array}{l}\text { Expecte } \\
\text { d sign }\end{array}$ \\
\hline Firm size & SIZE & $\begin{array}{l}\text { Natural } \underset{\text { logarithm of total }}{\text { asset }}\end{array}$ & $(-)$ \\
\hline Firm age & AGE & $\begin{array}{l}\text { Number of years listed on } \\
\text { HOSE or HNX until } 2018\end{array}$ & $(-)$ \\
\hline $\begin{array}{l}\text { Growth } \\
\text { opportunities }\end{array}$ & GROWTH & $\begin{array}{l}\text { MA/BA (Martket } \\
\text { value/Book value) }\end{array}$ & $(+) /(-)$ \\
\hline Business risk & RISK & $\begin{array}{l}\text { Standard deviation of } \\
\text { (EBITDA/Total asset) }\end{array}$ & $(+)$ \\
\hline $\begin{array}{l}\text { Free cash } \\
\quad \text { flow }\end{array}$ & FCF & $\begin{array}{l}\text { Natural logarithm of } \\
\text { operating cash flows minus } \\
\text { capital expenditures }\end{array}$ & $(+)$ \\
\hline \multirow{3}{*}{$\begin{array}{l}\text { Large } \\
\text { shareholder } \\
\text { ownership }\end{array}$} & LARGE & $\begin{array}{l}\text { Ownership ratio of large } \\
\text { shareholders* }\end{array}$ & $(-)$ \\
\hline & $\begin{array}{l}\text { LARGEST } \\
3\end{array}$ & $\begin{array}{l}\text { Ownership ratio of the three } \\
\text { largest shareholders }\end{array}$ & $(-)$ \\
\hline & $\begin{array}{c}\text { LARGEST } \\
1\end{array}$ & $\begin{array}{l}\text { Ownership ratio of the } \\
\text { largest shareholders }\end{array}$ & $(-)$ \\
\hline $\begin{array}{l}\text { Institutional } \\
\text { ownership }\end{array}$ & INST & $\begin{array}{l}\text { Ownership ratio of the large } \\
\text { shareholders who are } \\
\text { institutions }\end{array}$ & $(+) /(-)$ \\
\hline $\begin{array}{c}\text { State } \\
\text { ownership }\end{array}$ & SO & $\begin{array}{l}\text { Ownership ratio of State } \\
\text { shareholder }\end{array}$ & $(-)$ \\
\hline $\begin{array}{l}\text { Tangible } \\
\text { asset }\end{array}$ & TANG & Tangible asset/Total asses & $(-)$ \\
\hline $\begin{array}{l}\text { Sectoral } \\
\text { competition }\end{array}$ & HHI & $\begin{array}{l}\text { Sum of square of market } \\
\text { share of firms in the sector }\end{array}$ & $(+)$ \\
\hline $\begin{array}{l}\text { Sectoral } \\
\text { information }\end{array}$ & $\underset{\mathrm{D}}{\mathrm{RISK} I \mathrm{IN}}$ & $\begin{array}{l}\text { Standard deviation of } \\
\text { average EBIT by sector. }\end{array}$ & $(+)$ \\
\hline
\end{tabular}

* Large shareholder is a shareholder that directly or indirectly owns 5\% or more of the voting shares of the issuer.

(Source: Authors'review)

from 2007 to avoid missing observations due to differentiation and lagged- variables when using the Lintner model.

\section{Data source}

Dividend data and financial indicators are extracted from Stoxplus's data set. This data is collected from public information of the listed firms, such as: basic information of firms on securities firms' websites, audited annual financial statements, annual reports, notification of dividends. Therefore, we can easily control, update these data and calculate for specific indicators. Data in ownership structure, including: ownership of major shareholders, ownership of institutional shareholders and ownership of state shareholders are collected through Vietstock's annual data.

The sample consists of 336 listed firms, including 154 listed firms on HOSE (accounting for 45.83\%) and 182 listed firms on HNX (accounting for 54.17\%). The firms in the sample are divided into categories by industry, classified according to ICB level 1.

\section{EMPIRICAL RESUlts}

\section{A. Descriptive statistics analysis}

Descriptive statistics of the model's independent variables are presented in Table II.

Regarding the ownership structure, the ownership rate of all major shareholders (holding $5 \%$ or more shares) with the average level is $51.41 \%(51.92 \%)$, in which the average holding rate of 1 largest shareholder is $38.25 \%(40.78 \%)$ and that of 3 largest shareholders is $49.59 \%$ (51\%). With such a relatively close ownership ratio, it proves that the ownership structure in Vietnam is quite concentrated. The average shareholding rate of institutional shareholders excluding state shareholders is $14 \%$, maximum holding is $94.55 \%$ in the entire sample. The average value of State ownership is $29.39 \%$, the highest rate is $84.44 \%$. The average number of years of listing of listed firms during 20082018 is 10 years with the maximum value of 18 years and the minimum value of 6 years.

TABLE II

Descriptive Statistics

\begin{tabular}{|c|c|c|c|c|c|c|}
\hline & Mean & $\mathrm{Sd}$ & P50 & Min & Max & $\mathrm{Cv}$ \\
\hline LARGE & .5141 & .1946 & .5192 & 0 & .9517 & .3789 \\
\hline LARGEST1 & .3825 & .1820 & .4078 & 0 & .8295 & .4758 \\
\hline LARGEST3 & .4959 & .1923 & 0.51 & 0 & .9517 & .3880 \\
\hline INST & .1400 & .1936 & .0556 & 0 & .9455 & 1.41 \\
\hline $\mathrm{SO}$ & .2939 & .2386 & .3219 & 0 & .8444 & .8119 \\
\hline $\mathrm{AGE}$ & 10.06 & 2.23 & 10 & 6 & 18 & .2218 \\
\hline SIZE & 6.136 & 1.309 & 6.079 & 3.801 & 8.638 & .2134 \\
\hline GROWTH & 1.309 & 1.028 & .98 & .16 & 5.88 & .786 \\
\hline FCF & .1103 & .1016 & .0755 & .0063 & .3732 & .9210 \\
\hline RISK & .0455 & .0292 & .0398 & .0156 & .1778 & .5459 \\
\hline TANG & .4795 & .2113 & .4522 & .1564 & .8636 & .4407 \\
\hline HHI & .1014 & .1322 & .0442 & .0232 & .7954 & 1.304 \\
\hline RISK_IND & .0493 & .0080 & .0453 & .0361 & .0650 & .1632 \\
\hline
\end{tabular}

(Source: Authors' review)

The mean firm size (SIZE) is 6.136 with a maximum value of 8.638 and the minimum value of 3.801; The average value of the ratio of tangible assets to total assets TANG is $47.95 \%$ with a minimum value $15.64 \%$ and the maximum value of $86.36 \%$. The growth opportunity of a firm is calculated through the $\mathrm{M} / \mathrm{B}$ ratio, which averages out to 1.309 and takes on a value between 0.16 and 5.88. Free cash flow (FCF) is calculated as the natural logarithm of operating cash flows minus capital expenditures. The risk variable RISK is determined through the standard deviation of EBITDA/Total assets during 2008-2018, the mean value of the total sample of this variable is $4.55 \%$ with a minimum value of $1.56 \%$ and the maximum value $17.78 \%$.

Correlation testing (Table III) shows that most of the variables in the model are correlated with the dependent vari- 
TABLE III

Correlation Coefficients Matrix

\begin{tabular}{|c|c|c|c|c|c|c|c|c|c|c|c|c|}
\hline Variables & 1 & 2 & 3 & 4 & 5 & 6 & 7 & 8 & 9 & 10 & 11 & 12 \\
\hline 1. RelVol & 1.000 & & & & & & & & & & & \\
\hline 2. AGE & $-0.107^{* * *}$ & 1.000 & & & & & & & & & & \\
\hline 3. SIZE & $-0.139^{* * * *}$ & $0.176^{* * *}$ & 1.000 & & & & & & & & & \\
\hline 4. GROWTH & $0.054^{* * *}$ & -0.013 & $-0.040^{* *}$ & 1.000 & & & & & & & & \\
\hline 5. RISK & $-0.103^{* * *}$ & $-0.050^{* *}$ & $-0.073^{* * *}$ & $0.065^{* * *}$ & 1.000 & & & & & & & \\
\hline 6. FCF & -0.005 & $-0.032^{*}$ & $-0.170^{* * *}$ & $0.142^{* * *}$ & $0.168^{* * *}$ & 1.000 & & & & & & \\
\hline 7. LARGE & $0.034^{* *}$ & $0.037^{*}$ & $0.050^{* * *}$ & $0.041^{* *}$ & $0.101^{* * *}$ & $-0.041^{* *}$ & 1.000 & & & & & \\
\hline 8. INST & $-0.030^{*}$ & $0.081^{* *}$ & $0.096^{* * *}$ & $0.077^{* * *}$ & 0.006 & $0.089^{* * *}$ & $0.380^{* * *}$ & 1.000 & & & & \\
\hline 9. SO & $0.048^{* *}$ & -0.007 & $-0.031^{*}$ & -0.001 & $0.099^{* * * *}$ & 0.017 & $0.473^{* * * *}$ & $-0.361^{* * * *}$ & 1.000 & & & \\
\hline 10. TANG & 0.038 & $0.100^{* * * *}$ & $-0.340^{* * *}$ & $0.183^{* *}$ & $0.231^{* * * *}$ & $0.357^{* * *}$ & $0.055^{* *}$ & $0.116^{* * *}$ & $-0.028^{*}$ & 1.000 & & \\
\hline 11. HHI & $0.056^{* * *}$ & $-0.091^{* * *}$ & $0.050^{* * *}$ & 0.020 & $-0.032^{*}$ & $0.120^{* * *}$ & $0.075^{* * *}$ & $0.080^{* * *}$ & 0.006 & $0.096^{* * *}$ & 1.000 & \\
\hline 12. RISK_IND & $-0.083^{* * *}$ & $0.056^{* * *}$ & $0.183^{* * *}$ & 0.018 & $0.271^{* * *}$ & 0.021 & $0.099^{* * *}$ & 0.013 & $0.031^{*}$ & $0.031^{*}$ & $-0.117^{* * *}$ & 1.000 \\
\hline
\end{tabular}

(Source: Authors'review)

able, and the independent variables in the model are not likely to be linearly correlated.

Next, we carried out the necessary tests:

(I) Test of multicollinearity: There is no multicollinearity

(ii) Test of missing variables (Ramsey $\mathrm{E}(\mathrm{U} / \mathrm{X})=0)$ : The study added the age squared variable (AGE2) from the argument about the firm's development life cycle [12], giving Prob $>F=0.1465$, so the test results support the hypothesis H0: the model has no omitted variables.

(iii) Heteroskedasticity test: The model violates the hypothesis of no Heteroskedasticity.

(iv) Selection of instrument variables: In the research model, the variable RISK is measured by the standard deviation of EBIT. Therefore, the variable TANG can affect the level of RISK in the model due to the negative impact of using operating leverage with fixed operating costs (depreciation). Furthermore, activities in a high-risk sector can also affect corporate risks. Therefore, we suspects that the variable RISK will be explained by the variable TANG and RISK_IND in the regression model.

To test whether these variables can be selected as instrumental variables for business risk variables, the study examines the correlation between these variables with the residuals of the model. The test result shows that the correlation coefficients (pwcorr u tang risk_ind, sig) are all zero, proving that these variables are not correlated with the remainder. Thus, the research model is adjusted as follows::

$$
\operatorname{RelVol}_{i}\left(S O A_{i}\right)=\beta_{0}+\beta_{1} O W N_{i}+\beta_{2} A G E_{i}+\beta_{3} A G E 2_{i}
$$$$
+\beta_{4} S_{I I Z E_{i}}+\beta_{5} \text { GROWTH }_{i}+\beta_{6} \text { FCF }_{i}+\beta_{7} \text { RISK }_{i}+\beta_{8} H H I_{i}+\varepsilon_{i}
$$

\section{B. Results and discussion}

The results of OLS and 2SLS regressions show that there is no significant difference in the level of statistical significance and the direction of the impact of the independent variables on the dependent variable, except for INST. This can help the study confirm the robustness of the research results. Therefore, we will use the regression results of the 2SLS method for analysis.
TABLE IV

Summary of Regression Results

\begin{tabular}{|c|c|c|c|c|c|c|}
\hline & \multicolumn{3}{|c|}{ 2SLS regression with RelVol } & \multicolumn{3}{|c|}{ 2SLS regression with SOA } \\
\hline & (1) & (2) & (3) & (1) & (2) & (3) \\
\hline LARGE & $.1195^{* * *}$ & & & $0.0595^{* * *}$ & & \\
\hline INST & & -.0159 & & & $-.0477^{*}$ & \\
\hline SO & & & $.0753^{* * *}$ & & & $.0230^{* *}$ \\
\hline AGE & $.0282^{*}$ & $.0233^{*}$ & $.0234^{*}$ & $.0021^{* * *}$ & $.0024^{* * *}$ & $.0022^{* * *}$ \\
\hline AGE2 & $-.0019^{* * *}$ & $-.0017^{* *}$ & $-.0017^{* *}$ & $-.0056^{* * *}$ & $-.0630^{* * *}$ & $-.0595^{* *}$ \\
\hline SIZE & $-.0357^{* * *}$ & $-.0355^{* * *}$ & $-.0345^{* * *}$ & $-.0082^{* *}$ & $-.0079^{* *}$ & $-.0078^{* *}$ \\
\hline GROWTH & $.0202^{* * *}$ & $.0203^{* * *}$ & $.0216^{* * *}$ & $.1517^{* *}$ & $.1350^{* *}$ & $.1397^{* *}$ \\
\hline FCF & -.0228 & -.0544 & -.0351 & $-.0076^{*}$ & $-.0074^{*}$ & -.0060 \\
\hline RISK & $-1.978^{* * *}$ & $-1.504^{* * *}$ & $-1.692^{* * *}$ & $2.884^{* * *}$ & $2.6285^{* * *}$ & $2.505^{* * *}$ \\
\hline HHI & $.1177^{* * *}$ & $.1476^{* * *}$ & $.1367^{* * *}$ & $.0912^{* * *}$ & $.0839^{* * *}$ & $.1032^{* * *}$ \\
\hline Constant & $.9910^{* * *}$ & $1.053^{* * *}$ & $1.023^{* * *}$ & $.9384^{* * *}$ & $0.9624^{* * *}$ & $.9506^{* * *}$ \\
\hline $\mathrm{N}$ & 3562 & 3684 & 3583 & 3010 & 3113 & 3019 \\
\hline
\end{tabular}

Comparing the regression results according to the RelVol and SOA measures shows that most of the regression coefficients of the two models have the same impact. Particularly, the variables RISK, FCF and INST give heterogeneous results, in which FCF and INST are two variables that have no statistical relationship with the variable RelVol but have a relationship with the SOA at the significance level of $10 \%$ but the confidence interval being changed, so the study does not have a strong basis to conclude this relationship.

Regarding the RISK variable, as the hypothesis has been developed from the signaling theory, asymmetric information makes high-risk firms more inclined to stabilize dividends [20], [13]. Therefore, the RelVol regression model gives more suitable results. The variable RelVol is regressed over time by the RMSE method, while SOA is regressed according to the model of Litner with 2 independent variables, the more variables the more observations are required, so the reliability is reduced. At the same time, because the number of observations to measure SOA is small, this model 
has no economic significance and the results are not as reliable as the RelVol model. Therefore, the study will use the regression results with RelVol for analysis and discussion.

TABLE V

Summary Of Research Results On Theoretical Factors

\begin{tabular}{|c|c|c|c|c|}
\hline Theory & Factor & Variable & $\begin{array}{c}\text { Hypothesi } \\
\text { s }\end{array}$ & $\begin{array}{c}\text { Regression } \\
\text { result }\end{array}$ \\
\hline \multirow{6}{*}{$\begin{array}{l}\text { Agency } \\
\text { problem } \\
\text { (Agency } \\
\text { theory) }\end{array}$} & $\begin{array}{c}\text { Larger } \\
\text { ownership }\end{array}$ & LARGE & - & $\left(-^{* * *}\right)$ \\
\hline & $\begin{array}{l}\text { Institution } \\
\text { ownership }\end{array}$ & INST & + & \\
\hline & $\begin{array}{c}\text { State } \\
\text { ownership }\end{array}$ & $\mathrm{SO}$ & - & $\left(-^{* * *}\right)$ \\
\hline & $\begin{array}{c}\text { Growth } \\
\text { opportunity }\end{array}$ & GROWTH & - & $\left(-^{* * *}\right)$ \\
\hline & $\begin{array}{l}\text { Free cash } \\
\quad \text { flow }\end{array}$ & FCF & + & \\
\hline & $\begin{array}{c}\text { Sectoral } \\
\text { competitio } \\
n\end{array}$ & HHI & + & $\left(+^{* *}\right)$ \\
\hline \multirow{5}{*}{$\begin{array}{c}\text { Problem of } \\
\text { asymetric } \\
\text { information } \\
\text { (Asymetric } \\
\text { information) }\end{array}$} & Firm size & SIZE & - & $\left(+^{* * *}\right)$ \\
\hline & Firm age & AGE & - & $\begin{array}{l}\text { Non-linear } \\
\text { relationship } \\
\text { (U) }\end{array}$ \\
\hline & $\begin{array}{l}\text { Business } \\
\text { risk }\end{array}$ & RISK & + & $\left(+^{* * *}\right)$ \\
\hline & $\begin{array}{l}\text { Institution } \\
\text { ownership }\end{array}$ & INST & - & \\
\hline & $\begin{array}{c}\text { Growth } \\
\text { opportunity }\end{array}$ & GROWTH & + & $\left(-^{* * *}\right)$ \\
\hline
\end{tabular}

Table V presents a summary of the research results on the direction of impact according to the statistical significance of the factors

- As regard agency issue: The regression results of variables in this group show a significant consensus on the relationship between conflict of interest and dividend smoothing, consistent with the view of Easterbrook [10]; Allen et al [3]; DeAngelo and DeAngelo [8].

- As regards the issue of information asymmetry: As a result of regression with 5 variables in this group, only the variable firm's risk supports the theoretical sign. This is the variable identified as the endogenous variable in the model and is explained by the variable rate of tangible assets and sectoral risk. Firms that use operational leverage by investing heavily intangible assets and firms operating in sectors with a high level of information asymmetry in terms of access to information will face higher risks, and at that time the behaviour of dividend smoothing is found very clearly in high-risk firms.

As regards firm size: There exists a positive relationship between firm size and degree of dividend smoothing. This can be explained contrary to the agency theory. The larger the firm is, the more complex the organizational administration is. Thus, the conflicts of interest begin to increase and the agency cost will increase accordingly. Therefore, in order to minimize agency costs, these firms implement dividend smoothing policy.

As regards the variable firm age: The test result shows that there is a nonlinear relationship (U-shaped) between the firm age variable and the degree of dividend smoothing, with the minimum value is 10 years. This result can be explained through the business cycle and the development stage of the business, from inception to growth, the degree of stabilization gradually decreases; when moving to the saturation stage, the level of dividend smoothing will gradually increase.

\section{Conclusions}

From the above research results, there are some comments on the phenomenon of dividend smoothing in Vietnam as follows:

(i) Study results show significant consistency on the relationship between conflict of interest and dividend smoothing, confirming that the agency theory is appropriate to explain the smoothing behaviour of listed firms on Vietnam's stock market.

(ii) Smoothing of dividends in Vietnam is found more clearly in firms with large size and firms which have highprofit volatility. In contrast, firms that have centralized ownership structure; firms that are dominated by the State or hold a high ownership rate; firms that have many growth investment opportunities; firms that is in the stage of growth in the development cycle; firms that are operating in a low level of competition, are not suitable for selecting and maintaining stable dividend policy.

The research results can help stakeholders to identify characteristics of firms that tend to smooth dividends so that they can choose the suitable strategy.

Limitations: (i) There are many factors that can affect dividend smoothing behaviors but have not been taken into account in the model proposed in this research, such as forms of dividend payment or corporate governance and income management. The behavior of paying stock dividends or buying back shares of a firm may affect the behavior of dividend smoothing. (ii) The research objective is to provide information about the smoothing of dividends and not to assess whether the smoothing of dividends is good or not. Research results will not be enough to provide policy implications to encourage or limit this behaviour.

With some limitations of the research, the topic suggests further research directions through a number of unanswered questions such as: Does the form of paying stock dividends affect the behavior of dividend smoothing? Is dividend smoothing a behavior of income management? How does dividend smoothing affect firm value? In addition, further research can be implemented in the direction of considering the effects of macro factors.

\section{REFERENCES}

[1] Aivazian, V., L. Booth and S. Cleary, "Do emerging market firms follow different dividend policies from US firms?", Journal of Financial research, 26(3), 371-387, 2003.

[2] Ali, Z., A. Ullah and A. Ali, "Board structure and dividend smoothing: A case of Pakistani listed firms", Bussiness Review, 14(2), 65-91, 2019.

[3] Allen, F., A. E. Bernardo and I. Welch, "A theory of dividends based on tax clienteles", The Journal of Finance, 55(6), 2499-2536, 2000.

[4] Al-Najjar, B., and E. Kilincarslan, "Corporate dividend decisions and dividend smoothing: New evidence from an empirical study of Turkish firms", International Journal of Managerial Finance, 13(3), 304-331, 2017. 
[5] Baker, M., and J. Wurgler, "Investor sentiment and the cross-section of stock returns", Journal of Finance, 61, 1645-1680, 2006.

[6] Bhattacharya, S., "Imperfect information, dividend policy, and "the bird in the hand" fallacy", Bell journal of economics, 10(1), 259-270, 1979.

[7] Brennan, M. J., and A. V. Thakor, "Shareholder preferences and dividend policy", The Journal of Finance, 45(4), 993-1018, 1990.

[8] DeAngelo, H., and L. DeAngelo, "Capital structure, payout policy, and financial flexibility", Working paper, 2007.

[9] Dewenter, K. L., and V. A. Warther, "Dividends, asymmetric information, and agency conflicts: Evidence from a comparison of the dividend policies of Japanese and US firms", The Journal of Finance, 53(3), 879-904, 1998.

[10] Easterbrook, F. H., "Two Agency-Cost Explanations of Dividends", American Economic Review, 74(4), 650-659, 1984.

[11] Freeman, R. N., "The association between accounting earnings and security returns for large and small firms", Journal of Accounting and Economics, 9(2), 195-228, 1987.

[12] Grullon, G., M. Roni and S. Bhaskaran, "Are dividend changes a sign of firm maturity?”, The Journal of Business, 75, 387-424, 2002.

[13] Guttman, I., O. Kadan and E. Kandel, "Dividend stickiness and strategic pooling", Review of Financial studies, 23(12), 4455-4495, 2010.

[14] Harries, M., A. Raviv, "The theory of capital structure", Journal of Finance, 46, 297-355, 1991.

[15] Javakhadze, D., S. P. Ferris., and N. Sen., “An International Analysis of Dividend Smoothing”, Journal of Corporate Finance, 29, 200-220, 2014 .
[16] Jensen, M. C., and W. H. Meckling, "Theory of the firm: Managerial behavior, agency costs and ownership structure", Journal of financial economics, 3(4), 305-360, 1976.

[17] Jeong, J., "Determinants of dividend smoothing in emerging market: The case of Korea", Emerging Markets Review, 17, 76-88, 2013.

[18] Kighir, A. E., N. H. Omar., and N. Mohamed, "Corporate cash flow and dividends smoothing: a panel data analysis at Bursa Malaysia", Journal of Financial Reporting and Accounting, 13 (1), 2-19, 2015.

[19] Kumar, P., and B. Lee, "Discrete dividend policy with permanent earnings", Financial Management, 55-76, 2001.

[20] Kumar, P., "Shareholder-manager conflict and the information content of dividends", Review of Financial studies, 1(2), 111-136, 1988.

[21] La, P. R., F. L., A. Shleifer and R. Vishny , "Investor protection and corporate governance", Journal of financial economics, 58(1), 3-27, 2000.

[22] Lambrecht, B. M., and S. C. Myers, "A Litner Model of Payout and Managerial Rents", National Bureau of Economic Research, 2010.

[23] Leary, M. T., and M. Roni, "Determinants of dividend smoothing: Empirical evidence", Review of Financial studies, 24(10), 3197-3249, 2011.

[24] Lintner, J., "Distribution of Incomes of Corporations Among Dividends, Retained Earnings, and Taxes", American Economic Review, 46(2), 97-113, 1956.

[25] Michaely, R., and M. Roberts, "Dividend smoothing, agency costs, and information asymmetry: Lessons from the dividend policies of private firms", Unpublished working paper, 2006.

[26] Shinozaki, S., and K. Uchida, "Ownership Structure and Dividend Smoothing: International Evidence", Working Paper Faculty of Economics, Kyushu University, 2015. 